\title{
Evaluation towards internship program of vocational school students in automotive engineering
}

\author{
Sulasdi, Bambang Noor Achsan, Fatwa Tentama \\ Master Program of Vocational Education, Universitas Ahmad Dahlan, J1. Pramuka, \\ Yogyakarta, Indonesia \\ *Corresponding e-mail: sulasdi12@gmail.com
}

\begin{abstract}
The purpose of this evaluation research is to evaluate the implementation of the job training (internship) program at SMK Negeri Nusawungu, Cilacap, in automotive light vehicle engineering expertise in 2018/2019. The evaluation used the Context, Input, Process, Product (CIPP) model. This research involved the object of research of the implementation of internship program which is carried out at the SMK N Nusawungu Cilacap in automotive light vehicle engineering expertise in $2018 / 2019$. The data source in this study is the fieldwork practices and students in automotive light vehicle engineering expertise competencies who have implemented internship in the academic year 2018/2019. Students who were respondents were taken with a proportionate random sampling technique, the evaluation model used was the CIPP evaluation model with qualitative evaluation methods. Data collection was taken through questionnaires, interviews, and documentation. Data analysis uses descriptive statistics. The results suggest that the internship program was well run.
\end{abstract}

Keywords: automotive light vehicle engineering, CIPP, evaluation, internship

How to cite: Sulasdi, Achsan, B. N., \& Tentama, F. (2020). Evaluation towards internship program of vocational school students in automotive engineering. International Journal on Education Insight, 1(1), 41-60. DOI: http://dx.doi.org/10.12928/ijei.v1i1.2116.

\section{INTRODUCTION}

The number of unemployed graduates of vocational high schools (SMK) is of particular concern to the Ministry of Education and Culture of the Republic of Indonesia. The percentage of unemployment open to SMK graduates in August 2017 reached 11.41 percent, an increase from the previous year which was still below 10 percent (Kompas, 2017).

The factors that cause SMK graduates to be absorbed less in the world of work are the skills and readiness of students entering the workforce. The results of observations made by the 5 vocational high schools in the Cilacap Regency showed that the skills of students were not optimal. This deficiency is shown by: (1) implementation of street vendors that are not optimal, (2) the level of student confidence is still low, (3) student competencies are lacking, and (4) students' ability to face and overcome problems when street vendors are still lacking. On this basis, the government seeks to optimize the function of vocational schools by revitalizing vocational schools in the hope that all graduates will be able to work, become entrepreneurs or work independently.

The main objective of SMK / MAK is to prepare graduates who are ready to work in their fields. Vocational Schools aim to produce graduates who are ready to work, entrepreneurial, intelligent, competitive, have a national identity, can develop local excellence and can compete in the global market. Vocational 
Schools are required to produce learning outcomes that are suitable to the needs of the workforce (Wagiran, 2018).

To produce graduates who can be absorbed in the business world and the industrial world (Du-Di), the school implements a Dual Systems Education (PSG) program to equip students with skills. There are still many SMK graduates who are not yet skilled and do not yet have a certificate of expertise. Dual System Education (PSG) is a form of organizing professional skills education that systematically and synchronizes the education program in schools and the mastery program obtained through direct work activities in the world of work, directed to achieve a certain level of professional expertise.

PSG is a strategy that brings students closer to the world of work and this is a proactive strategy that demands changes in attitudes and mindsets and functions of education practitioners at the vocational level, the community, and the business/industry world in responding to these dynamic changes. The purpose of implementing PSG is to bring the supply and demand of HR quality closer. especially those related to the quality of employment. Vocational School as a provider of human resources and the world of work and the community as parties in need (Badeni, 2002).

"The dual system education model (dual system) is a system that is effective enough to educate and prepare someone to deepen and master complex skills that are not possible or have never been done in schools" (Pardjono, 2011).

The learning/training process in the world of work is intended so that students master standardized competencies, develop and internalize professional attitudes and values as a superior quality workforce, both working for other parties and as independent workers. Before actualizing it, preparations are needed which include an inventory of learning resources and an assessment of learning readiness. Inventory of learning places suitable for competencybased learning is a place where the competencies learned are implemented (the real world of work), or at least a replica of the actual conditions.

Industrial Work Practices (Prakerin) or Field Work Practices (PKL) is a pattern of organizing learning following the PSG program. Students do practical internships (apprenticeships) in industries that are relevant to their expertise program for a certain period. PKL will describe the involvement of students in a real job according to their field of expertise, besides, students will gain experience to expand their knowledge of the world of work. The implementation of street vendors will indirectly provide knowledge and experience at work. The experience gained when implementing street vendors in the industry, in addition to learning how to get a job, also learning how to have jobs that match the talents and interests possessed by these students. Experience, in this case, is the experience gained after implementing Field Work Practices in Industry, this work experience will determine students' readiness to work because in industry students are taught to work according to their abilities.

"The implementation of the machinery faces many obstacles, including (1) geographical diversity; (2) diversity of SMK readiness and competence; (3) diversity of SMK programs that are not supported by the presence of industry in the area concerned; (4) ineffective guidance counselors from schools and industry instructors; (5) difficulty in establishing cooperation with partner institutions (IP); and (6) weak management of training in the industry (Sonhadji, 2012).

Barriers to the implementation of street vendors include; (1) Du-Di's confidence in student competencies is still very low; (2) the street vendors are 
not in accordance with the competency of expertise; (3) there are too many PKL participants, so the guidance is not optimal; (4) time PKL is not effective.

These problems make Du-Di and government agencies feel less confident about the quality of vocational students. PKL activities are expected to provide additional knowledge and new skills for students so that their work experience can be useful. Schools and industry are expected to improve the quality of fieldwork practice programs, together with SMKs and industry / professional associations as partner institutions (IP), starting from the planning, implementation to evaluation and certification stages which constitute an integrated program by using various alternative forms of implementation " The assessed aspects are the effectiveness of industrial work practices programs with assessment indicators: planning of industrial work practices, namely students' understanding of internship and pre-industrial activities, implementation of industrial work practices, namely activities during internship, evaluation, and certification of industrial work practices, namely activities after internship (Dikmenjur, 2008).

This article aims to evaluate the implementation of street vendors in SMK Negeri Nusawungu, Cilacap district, competency in Light Vehicle Engineering expertise using the Context, Input, Process, Product (CIPP) method or model.

The objectives to be achieved are 1) Describe the context in the PKL Nusawungu District Cilacap District Vocational program in terms of the objectives of the program and the environment in which the PKL program is 2) Describe the input in the PKL Nusawungu District Vocational Program in Cilacap Regency reviewed from supporting infrastructure, PKL funding sources and PKL relevance with student needs, 3) Describe the process of implementing industrial work practices in SMK Negeri Nusawungu Cilacap Regency in terms of preparation, implementation, monitoring, pick-up and obstacles in implementing PKL programs, 4) Describe the results (product) that has been achieved from the PKL vocational program Nusawungu State Cilacap Regency in terms of student PKL grades and competency test scores.

\section{RESEARCH METHOD}

This type of research is an evaluation study using the Context, Input, Process, Product (CIPP) model. "Evaluative research is needed to design, refine and test the implementation of a practice" (Sukmadinata, 2009). The researcher evaluates the PKL program in SMK Negeri Nusawungu, Cilacap Regency, which is evaluated from the Context, Input, Process, Product (CIPP). This research is expected to be able to know the description of the implementation of street vendors in the State Vocational School Nusawungu Cilacap Regency.

Qualitative research methods are research methods used to examine the condition of natural objects, where the researcher is a key instrument (Sugiono, 2012). Data collection techniques are carried out jointly (triangulated) data analysis is inductive, and the results of qualitative research emphasize meaning rather than generalization.

This research was conducted at the State Vocational School Nusawungu Cilacap District. The informants of this study were the PKL Working Group under the coordination of the Vice-Principal in the field of public relations, including; PKL Coordinator staff, PKL secretary, PKL Treasurer, Expert Competency Chair, Teacher Guidance and Nusawungu State Vocational School students in Cilacap Regency who sit in class XI all expertise Competencies who have implemented PKL in the 2018-2019 Academic Year. Street vendors carried out for 6 months, which are divided into 2 waves. The first wave was in the odd 
semester of July 2018 until December 2018 and the second wave was in the even semester of February 2019 to April 2019.

\section{CIPP Evaluation Model}

Arikunto \& Jabar (2004) stated that CIPP is an abbreviation of the initial four words: (1) Context Evaluation; Context evaluation is an attempt to describe and detail the environment, unmet needs, populations and samples served, and project objectives. (2) Input Evaluation; Input evaluation is the initial ability of students and schools in supporting PMTAS, including the ability of schools to provide appropriate staff, reliable menu regulators, qualified health experts and so on. (3) Process Evaluation; Process evaluation is directed at the extent to which the activities carried out in the program have been carried out according to plan. The evaluation of the process in the CIPP model refers to "what" activities carried out in the program, "who" (who) the person is appointed to be responsible for the program, "when" the activities will be completed. (4) Product Evaluation; Evaluation of products or results is directed at things that show the changes that occur in raw input.

Sukardi (2011: 63), states that the CIPP evaluation model, there are four types of evaluation focus, namely: (1) Context Evaluation; Generate information about the various needs that have been set priorities, so that goals can be formulated. (2) Input Evaluation; Provides information about the selected input, points of strength and weakness, strategy, and design to realize the objectives.

(3) Process Evaluation; Provides information for evaluators to carry out selected monitoring procedures that may be newly implemented so that strong items can be utilized and weak ones can be removed. (4) Product Evaluation; Accommodate information to ensure under what conditions the objectives can be achieved and also to determine if the strategies related to procedures and methods applied to achieve the objectives should stop, modify or continue in their current form.

\section{Data Collection Tools}

Data collection tools must be carefully chosen and designed. A good data collection tool must have clear guidelines so that the research process workflow can run smoothly. In this study, the data collection tools used are: questionnaire, documentation, and interview.

\section{Questionnaire}

Wirawan (2011:186) states that the research instruments most widely used in evaluations in particular and generally are questionnaires. Questionnaires are written questions that must be answered by respondents in writing. Sugiyono (2012:199) states the questionnaire is a data collection technique by giving a set of questions to respondents to answer. The questionnaire used in this study included in the type of closed questionnaire, closed questionnaire or structured questionnaire (closed questionnaire $=$ structured questionnaire) is a questionnaire for which alternative answers have been provided (Wirawan, 2011:186). The reasons for using a closed questionnaire or closed questionnaire (closed questionnaire $=$ structured questionnaire) are: (1) The questions and alternative answers to this questionnaire are the same for each respondent, (2) The answers obtained are easily processed using statistics, (3) The process of presenting data is easier to communicate.

In preparing the questionnaire, the researcher took several steps, namely: (1) Look for and determine appropriate theoretical studies and are related to the title and theme of the study; (2) Look for existing research references and in line 
with research; (3) Combining theoretical studies with consistent research references; (4) Determine the grid, choose the form and format of the questionnaire; (5) Determining the scale used, in this study the scale used is the Likert scale; (6) Questionnaires that have been made are validated by consulting expert experts; (7) Make revisions until the questionnaire that has been prepared by researchers is ready to use.

Data were taken through a questionnaire using a Likert scale with 4 alternative answers namely; does not match (TS) the value is 1, less appropriate (KS) the value is 2 , according to (S) the value is 3 and it is very appropriate (SS) the value is 4 . Each question item is analyzed in percentage, the aim is that the data taken can describe the suitability of each indicator. In collecting data, it is necessary to be guided by the indicators determined, along with the grid and guidelines in making the questionnaire.

The indicators of the questionnaire are presented in Table 1.

Table 1. Questionnaire Guide

\begin{tabular}{|c|c|c|c|}
\hline & Variable & Sub Variable & Indicator \\
\hline \multirow{2}{*}{\multicolumn{2}{|c|}{$\begin{array}{l}\text { 1. Context } \\
\text { Evaluation }\end{array}$}} & $\begin{array}{l}\text { a. General } \\
\text { description }\end{array}$ & $\begin{array}{l}\text { 1) Understanding of Field Work Practices } \\
\text { 2) Purpose of Field Work Practices (PKL) } \\
\text { 3) Readiness DUDI Field Work Practices } \\
\text { 4) Field Work Practices participant } \\
\text { readiness }\end{array}$ \\
\hline & & $\begin{array}{l}\text { b. Conformity with } \\
\text { the objectives of } \\
\text { the Field Work } \\
\text { Practices }\end{array}$ & $\begin{array}{l}\text { 1) Compliance with the objectives of the } \\
\text { Field Work Practices }\end{array}$ \\
\hline & $\begin{array}{l}\text { Input } \\
\text { Evaluation }\end{array}$ & $\begin{array}{l}\text { Strategy and design } \\
\text { to realize the goal }\end{array}$ & $\begin{array}{l}\text { 1) Compliance with the requirements } \\
\text { needed by students before Field Work } \\
\text { Practices } \\
\text { 2) The suitability of the preparation } \\
\text { students must do before Field Work } \\
\text { Practices }\end{array}$ \\
\hline & $\begin{array}{l}\text { Process } \\
\text { Evaluation }\end{array}$ & $\begin{array}{l}\text { The process of } \\
\text { implementing Field } \\
\text { Work Practices }\end{array}$ & $\begin{array}{l}\text { 1) Information regarding the } \\
\text { implementation of Field Work Practices } \\
\text { 2) The process of implementing students } \\
\text { when carrying out Field Work Practices } \\
\text { in the industrial world } \\
\text { 3) The process of completing reports and } \\
\text { practical tests after students carry out } \\
\text { Field Work Practices in the industrial } \\
\text { world } \\
\text { 4) The role of the Coordinator/chairman of } \\
\text { the Field Work Practice section } \\
\text { 5) The role of the internal tutor } \\
\text { 6) The role of mentors from the industrial } \\
\text { world (external) }\end{array}$ \\
\hline & $\begin{array}{l}\text { Product } \\
\text { Evaluation }\end{array}$ & $\begin{array}{l}\text { Conformity of the } \\
\text { objectives to be } \\
\text { achieved }\end{array}$ & $\begin{array}{l}\text { Conformity with the objectives of the Field } \\
\text { Work Practices }\end{array}$ \\
\hline
\end{tabular}

After the questionnaire is ready, the data collection process is carried out, the steps taken by the researchers to do the data are: (1) Contact the Field Work Practice Working Group as a sample; (2) Asking for help teachers distribute 
questionnaires that have been prepared; (3) Assisting if the respondent encounters obstacles in filling out the questionnaire; (4) The questionnaire was taken back after the respondent finished filling out the questionnaire.

\section{Documentation}

Arikunto (2010), explained that the method of documentation is looking for data about things or variables in the form of notes, transcripts, books, newspapers, magazines, inscriptions, minutes of meetings, lengths, agendas and so on. The documentation carried out in this study includes searching for documents, the documents sought are the manual of the implementation of the job Training and student data.

Data obtained through documentation is used by researchers as secondary data or supporting data relevant to the research theme. In collecting data, it is necessary to be guided by the indicators specified. The documentation guidelines is presented in Table 2 .

Table 2. Documentation Guidelines

\begin{tabular}{|c|c|c|c|c|}
\hline Variable & $\begin{array}{c}\text { Sub } \\
\text { Variable }\end{array}$ & Indicator & Sub Indicator & Data source \\
\hline \multirow[t]{2}{*}{$\begin{array}{l}\text { Context } \\
\text { Evaluation }\end{array}$} & $\begin{array}{l}\text { General } \\
\text { description }\end{array}$ & $\begin{array}{l}\text { Definition of } \\
\text { Field Work } \\
\text { Practices }\end{array}$ & $\begin{array}{l}\text { Describe the } \\
\text { understanding of Field } \\
\text { Work Practices }\end{array}$ & $\begin{array}{l}\text { Data/reference } \\
\text { book }\end{array}$ \\
\hline & & $\begin{array}{l}\text { Population } \\
\text { and sample }\end{array}$ & $\begin{array}{l}\text { Describe the } \\
\text { understanding of } \\
\text { Population and }\end{array}$ & $\begin{array}{l}\text { Data/books from } \\
\text { the Workgroup } \\
\text { fieldwork Practices }\end{array}$ \\
\hline $\begin{array}{l}\text { Context } \\
\text { Evaluation }\end{array}$ & $\begin{array}{l}\text { General } \\
\text { description }\end{array}$ & $\begin{array}{l}\text { The function of } \\
\text { Field Work } \\
\text { Practices }\end{array}$ & $\begin{array}{l}\text { Describe the objectives } \\
\text { of the Field Work } \\
\text { Practice }\end{array}$ & Guide book \\
\hline $\begin{array}{l}\text { Input } \\
\text { Evaluation }\end{array}$ & - & 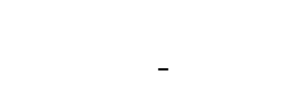 & 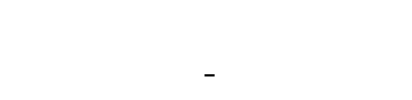 & - \\
\hline $\begin{array}{l}\text { Process } \\
\text { Evaluation }\end{array}$ & $\begin{array}{l}\text { The process } \\
\text { implementin } \\
\text { Field Work } \\
\text { Practices }\end{array}$ & fWorking Group & $\begin{array}{l}\text { Propose participants } \\
\text { for the Field Work } \\
\text { Practice briefing to } \\
\text { the Vice-Principal in } \\
\text { School Public } \\
\text { Assign } . \\
\text { Guidance and Field } \\
\text { Work Pracher } \\
\text { examiners with the } \\
\text { approval of the } \\
\text { Fvnertice a database } \\
\text { Develop a diatice } \\
\text { (database) where the } \\
\text { Job Training, and } \\
\text { update it regularly }\end{array}$ & $\begin{array}{l}\text { Data/book from } \\
\text { the Field Work } \\
\text { Practice } \\
\text { coordinator } \\
\text { Data/book from } \\
\text { the Field Work } \\
\text { Practice } \\
\text { coordinator } \\
\text { Data/book from } \\
\text { the Field Work } \\
\text { Practice } \\
\text { coordinator }\end{array}$ \\
\hline $\begin{array}{l}\text { Product } \\
\text { Evaluation }\end{array}$ & - & - & - & - \\
\hline
\end{tabular}

\section{Interview}

Sugiyono (2012) states that the interview is used as a data collection technique if the researcher wants to conduct a preliminary study to find problems that 
need to be investigated, and also if he wants to know things from respondents in more depth and the number of respondents is small.

Wirawan (2011) stated that the interview is a direct conversation between the interviewer (interviewer) with the interviewee (interviewee) through certain media, namely: (1) Meet face to face between the interviewer or the interviewer with the interviewee; (2) Use a telephone or telephone interview; (3) Using a teleconference communication system.

The interview method used is a structured interview method, with respondents in the Field Work Practice Coordinator Competency in Automotive Light Vehicle Engineering Expertise, the interviews conducted aim to capture data related to Field Work Practices, such as: (1) Information about who is appointed as the person in charge of the Field Work Practices; (2) Information regarding the time of implementation of the Field Work Practices; (3) Information regarding obstacles to the implementation of Field Work Practices.

In collecting data, it is necessary to be guided by the indicators specified, along with the interview guidelines used as presented in Table 3.

Table 3. Interview Guidelines

\begin{tabular}{lcllc}
\hline Variable & $\begin{array}{c}\text { Sub } \\
\text { Variable }\end{array}$ & Indicator & \multicolumn{1}{c}{ Sub Indicator } & $\begin{array}{c}\text { Data } \\
\text { source }\end{array}$ \\
\hline $\begin{array}{l}\text { Context } \\
\text { Evaluation }\end{array}$ & $\begin{array}{c}\text { General } \\
\text { Description }\end{array}$ & $\begin{array}{l}\text { Describe the } \\
\text { understanding of Field } \\
\text { Work Practices }\end{array}$ & $\begin{array}{l}\text { Chair of the Field Work } \\
\text { Practice Working Group } \\
\text { and Chair of expertise } \\
\text { competencies }\end{array}$ & 1 \\
& & & &
\end{tabular}

Input

Evaluation

Process The process ofInformation about who Chair of the Field Work

Evaluatio implementing is appointed as the Practice Working Group

$\mathrm{n} \quad$ Field Work person in charge of the and Chair of expertise

Practices Field Work Practices competencies

Information about time Chair of the Field Work

Implementation of Field Practice Working Group

Work Practices and Chair of expertise competencies

Information regarding Chair of the Field Work constraints Practice Working Group

Implementation of Field and Chair of expertise

Work Practices competencies

Product

Evaluation

\section{Data Analysis}

The purpose of this evaluation study was to determine the suitability of the implementation of the Field Work Practice based on the Automotive Light Vehicle Engineering Field Work Manual guidebook for Nusawungu State Vocational School 2018/2019, in terms of Context Evaluation, Input Evaluation, Process Evaluation dan Product Evaluation.

The data analysis technique was carried out qualitatively, namely through 1) data collection through questionnaires, observations, interviews, 2) data presentation, 3) data reduction, 4) conclusion. 


\section{RESULTS AND DISCUSSION}

The results of this research is presented in the following section.

\section{Research Data}

\section{Context Evaluation}

Data collection in context evaluation is divided into several sub-variables and several indicators, sub-variables in Context Evaluation are (1) General description, and (2) Compliance with the objectives of the Field Work Practice.

This sub variable is broken down based on several indicators, the intended indicators are as follows: (1) General description, including: Definition of Field Work Practices, Population and sample, Purpose of Field Work Practices; (2) Compliance with the objectives of the Field Work Practices. The data measured in the general variable sub-variable which includes three indicators namely the understanding of Field Work Practices, population and sample as well as industry objectives are summarized in the general work section sub-chapter of the implementation of the fieldwork practice in automotive Light Vehicle Engineering Skills Competency, while for sub-variables in accordance with the objectives Field Work Practices are obtained through a questionnaire with 8 questions given to students who carry out Field Work Practices in the $2018 / 2019$ academic year as respondents, following the results of data obtained from questionnaires that have been compiled by researchers, as presented in Table 4.

Table 4. Respondents' answer in the context evaluation questionnaire.

\begin{tabular}{|c|c|c|c|c|c|c|c|c|}
\hline \multirow{3}{*}{$\begin{array}{c}\text { item } \\
\text { questions } \\
\text { to }\end{array}$} & \multicolumn{8}{|c|}{ the number who answered } \\
\hline & \multicolumn{2}{|c|}{ not appropriate } & \multicolumn{2}{|c|}{ less appropriate } & \multicolumn{2}{|c|}{ appropriate } & \multicolumn{2}{|c|}{ verry appropriate } \\
\hline & $\begin{array}{c}\text { number of } \\
\text { Respondents }\end{array}$ & $\%$ & $\begin{array}{c}\text { number of } \\
\text { Respondents } \\
\end{array}$ & $\%$ & $\begin{array}{c}\text { number of } \\
\text { Respondents }\end{array}$ & $\%$ & $\begin{array}{c}\text { number of } \\
\text { Respondents }\end{array}$ & $\%$ \\
\hline 1 & 0 & 0,00 & 0 & 0,00 & 18 & 47,37 & 20 & 52,63 \\
\hline 2 & 1 & 2,63 & 3 & 7,89 & 11 & 28,95 & 23 & 60,53 \\
\hline 3 & 0 & 0,00 & 0 & 0,00 & 13 & 34,21 & 25 & 65,79 \\
\hline 4 & 0 & 0,00 & 0 & 0,00 & 21 & 55,26 & 17 & 44,74 \\
\hline 5 & 0 & 0,00 & 0 & 0,00 & 17 & 44,74 & 21 & 55,26 \\
\hline 6 & 5 & 13,16 & 1 & 2,63 & 18 & 47,37 & 14 & 36,84 \\
\hline 7 & 0 & 0,00 & 1 & 2,63 & 24 & 63,16 & 13 & 34,21 \\
\hline 8 & 0 & 0,00 & 0 & 0,00 & 6 & 15,79 & 32 & 84,21 \\
\hline Jumlah & \multicolumn{2}{|l|}{6} & \multicolumn{2}{|l|}{5} & \multicolumn{2}{|c|}{128} & \multicolumn{2}{|c|}{165} \\
\hline $\begin{array}{c}\text { Persentase } \\
(\%) \\
\end{array}$ & \multicolumn{2}{|l|}{1,97} & \multicolumn{2}{|l|}{0,82} & \multicolumn{2}{|c|}{14,04} & \multicolumn{2}{|c|}{13,57} \\
\hline
\end{tabular}

Based on Table 4, it can be seen that the tendency of respondents to answer alternative answers is very appropriate at a maximum of $84.21 \%$ and a minimum of $34.21 \%$. Corresponding answers' appropriate to a maximum of $63.16 \%$ and a minimum of $15.79 \%$ which are depicted in red and corresponding to green. less appropriate answers are at a maximum of $7.89 \%$ and a minimum of $0.00 \%$. not appropriate answers are at a maximum of $13.16 \%$ and a minimum of $0.00 \%$ ie on the instrument items as presented in Table 5. 
Table 5. Respondents' positive answer in the context evaluation questionnaire.

\begin{tabular}{clccc}
\hline $\begin{array}{c}\text { Item } \\
\text { Number }\end{array}$ & \multicolumn{1}{c}{ Instrumen question Item } & $\begin{array}{l}\text { The } \\
\text { answer }\end{array}$ & amount & Percentage \\
\hline 2 & $\begin{array}{l}\text { Field Work Practice Participants } \\
\text { understand about the Job } \\
\text { Training Briefing material } \\
\text { provided by schools before } \\
\text { carrying out Field Work Practices }\end{array}$ & $\begin{array}{l}\text { less } \\
\text { appropriate } \\
\text { and not } \\
\text { appropriate }\end{array}$ & 4 & $10,51 \%$ \\
& $\begin{array}{l}\text { DUDI as a place for Field Work } \\
\text { Practice has a production/service } \\
\text { process activity (routine work), so } \\
\text { that Field Work Practice students } \\
\text { are not too often unemployed }\end{array}$ & $\begin{array}{l}\text { less } \\
\text { appropriate }\end{array}$ & 6 & $15,79 \%$ \\
& & & \\
\hline
\end{tabular}

\section{Input Evaluation}

Data collection in the Input Evaluation details the strategy and design subvariables to realize the objectives, these sub-variables are translated into several indicators, namely as follows: (1) Compliance with the general requirements of the environment in which students practice Field Work; (2) The suitability of the preparation that students must do before carrying out the Job Training. The Job Training Handbook outlines the general requirements for the preparation of the Job Training for DUDI and students, detailed as follows: (1) The selection of the location of the Field Work Practice that already has an MOU with the school; (2) DUDI is following the competence of the participants in the Field Work Practices; (3) DUDI has a business license and a clear place; (4) Has complete infrastructure and routine work; (5) DUDI has a program that supports the Field Work Practice.

Student requirements before carrying out Field Work Practices are: (1) Students already have sufficient competence to attend Field Work Practices; (2) Students submit a DUDI Field Work Practice; (3) Schools circulate cover letters and applications for Field Work Practices to DUDI; (4) DUDI gave a reply to the Job Training; (5) The school determines the supervisor of Field Work Practices. Indicators of the achievement of the requirements needed by students before starting the Field Work Practice and the achievement of the preparations that must be done by students before carrying out the Field Work Practice are measured through a questionnaire with 20 questions given to students who carry out Field Work Practice 2018/2019 academic year as respondents, the following results which is obtained, as presented in Table 6.

In Table 6 , the answers are very appropriate at a maximum of $89.47 \%$ and a minimum of $34.21 \%$. Corresponding answers appropriate to a maximum of $57.89 \%$ and a minimum of $10.53 \%$ which are depicted in red and green. The answers are less appropriate for a maximum of $26.32 \%$ and a minimum of $0.00 \%$. not appropriate answers are at a maximum of $18.42 \%$ and a minimum of $0.00 \%$. 
Table 6. Respondents answer on the Input Evaluation Questionnaire.

\begin{tabular}{|c|c|c|c|c|c|c|c|c|}
\hline \multirow{3}{*}{ item questions to } & \multicolumn{8}{|c|}{ the number who answered } \\
\hline & \multicolumn{2}{|c|}{ not appropriate } & \multicolumn{2}{|c|}{ less appropriate } & \multicolumn{2}{|c|}{ appropriate } & \multicolumn{2}{|c|}{ verry appropriate } \\
\hline & $\begin{array}{c}\text { number of } \\
\text { Respondents }\end{array}$ & $\%$ & $\begin{array}{c}\text { number of } \\
\text { Respondents }\end{array}$ & $\%$ & $\begin{array}{c}\text { number of } \\
\text { Respondents }\end{array}$ & $\%$ & $\begin{array}{c}\text { number of } \\
\text { Respondents }\end{array}$ & $\%$ \\
\hline 1 & 0 & 0,00 & 0 & 0,00 & 7 & 18,42 & 31 & 81,58 \\
\hline 2 & 0 & 0,00 & 0 & 0,00 & 8 & 21,05 & 30 & 78,95 \\
\hline 3 & 0 & 0,00 & 0 & 0,00 & 4 & 10,53 & 34 & 89,47 \\
\hline 4 & 7 & 18,42 & 3 & 7,89 & 6 & 15,79 & 22 & 57,89 \\
\hline 5 & 5 & 13,16 & 5 & 13,16 & 13 & 34,21 & 15 & 39,47 \\
\hline 6 & 0 & 0,00 & 10 & 26,32 & 13 & 34,21 & 15 & 39,47 \\
\hline 7 & 0 & 0,00 & 1 & 2,63 & 19 & 50,00 & 18 & 47,37 \\
\hline 8 & 1 & 2,63 & 6 & 15,79 & 13 & 34,21 & 18 & 47,37 \\
\hline 9 & 0 & 0,00 & 2 & 5,26 & 19 & 50,00 & 17 & 44,74 \\
\hline 10 & 0 & 0,00 & 1 & 2,63 & 15 & 39,47 & 22 & 57,89 \\
\hline 11 & 0 & 0,00 & 4 & 10,53 & 7 & 18,42 & 27 & 71,05 \\
\hline 12 & 0 & 0,00 & 5 & 13,16 & 20 & 52,63 & 13 & 34,21 \\
\hline 13 & 0 & 0,00 & 2 & 5,26 & 22 & 57,89 & 14 & 36,84 \\
\hline 14 & 0 & 0,00 & 1 & 2,63 & 8 & 21,05 & 29 & 76,32 \\
\hline 15 & 0 & 0,00 & 0 & 0,00 & 17 & 44,74 & 21 & 55,26 \\
\hline 16 & 0 & 0,00 & 0 & 0,00 & 14 & 36,84 & 24 & 63,16 \\
\hline 17 & 0 & 0,00 & 0 & 0,00 & 10 & 26,32 & 28 & 73,68 \\
\hline 18 & 0 & 0,00 & 2 & 5,26 & 8 & 21,05 & 28 & 73,68 \\
\hline 19 & 0 & 0,00 & 0 & 0,00 & 8 & 21,05 & 30 & 78,95 \\
\hline 20 & 0 & 0,00 & 3 & 7,89 & 7 & 18,42 & 28 & 73,68 \\
\hline Jumlah & 0 & & 20 & & 155 & & 28 & \\
\hline $\begin{array}{c}\text { Persentase } \\
(\%)\end{array}$ & 0,00 & & 3,29 & & 17,0 & & 23, & \\
\hline
\end{tabular}

The instruments are as presented in Table 7.

Table 7. Respondents' answer on input questionnaire

\begin{tabular}{|c|c|c|c|c|}
\hline $\begin{array}{c}\text { Item } \\
\text { Number }\end{array}$ & Instrumen question Item & $\begin{array}{c}\text { The } \\
\text { answer }\end{array}$ & amount & Percentage \\
\hline 4 & $\begin{array}{l}\text { DUDI where the Field Work } \\
\text { Practice has more than } 1 \\
\text { employee }\end{array}$ & $\begin{array}{l}\text { less } \\
\text { appropriate } \\
\text { and not } \\
\text { appropriate }\end{array}$ & 10 & $26,32 \%$ \\
\hline 5 & $\begin{array}{l}\text { DUDI where the Field Work } \\
\text { Practice has a clear division of } \\
\text { tasks }\end{array}$ & $\begin{array}{l}\text { less } \\
\text { appropriate } \\
\text { and not } \\
\text { appropriate }\end{array}$ & 10 & $26,32 \%$ \\
\hline 6 & $\begin{array}{l}\text { DUDI Field Work Practice places } \\
\text { have space/place of practice that } \\
\text { is safe and protected (K3) }\end{array}$ & $\begin{array}{l}\text { less } \\
\text { appropriate }\end{array}$ & 10 & $26,32 \%$ \\
\hline
\end{tabular}




\begin{tabular}{lllcc}
\hline 11 & $\begin{array}{l}\text { he time for implementing the Job } \\
\text { Training for 6 months (either } \\
\text { directly or interrupted 3 months- }\end{array}$ & $\begin{array}{l}\text { less } \\
\text { appropriate }\end{array}$ & 4 & $10,53 \%$ \\
\hline $\begin{array}{l}3 \text { months) } \\
\text { Participants in the Field Work }\end{array}$ & $\begin{array}{l}\text { less } \\
\text { Practice have sufficient } \\
\text { knowledge and skills preparation }\end{array}$ & 5 & $13,16 \%$ \\
20 & $\begin{array}{l}\text { The Field Work Practices } \\
\text { working group recapitulates } \\
\text { DUDI where the Field Work } \\
\text { Practices work and assigns a } \\
\text { Mentor to each participant in the } \\
\text { Field Work Practice }\end{array}$ & $\begin{array}{l}\text { less } \\
\text { appropriate }\end{array}$ & 3 & $7,89 \%$ \\
& & & \\
\hline
\end{tabular}

\section{Process Evaluation}

The data to be measured and analyzed in the process evaluation is taken through interviews and questionnaires, data collection in the process evaluation details the sub-variables of the process of implementing the Field Work Practices, these sub-variables are broken down into several indicators, the intended indicators are as follows: (1) Information regarding the implementation of Field Work Practices; (2) The process of implementing students when carrying out Field Work Practices in the industrial world; (3) The process of completing reports and practical tests after students carry out Field Work Practices in the industrial world; (4) The Role of the Field Work Practice Coordinator; (5) The role of school and industry supervisors.

The data on point indicators number two through number six are collected through a questionnaire, the number of questions to describe the 5 indicators is 32 items with 4 alternative answers that are very appropriate, appropriate, not suitable and the last is not very suitable, 34 of these questions are given to students carrying out Field Work Practice 2018/2019 academic year. as a respondent, the following results of the data obtained from the questionnaire that was compiled by researchers.

In Figure 1, it can be seen that the respondents' tendency to answer is very appropriate at a maximum of $84.21 \%$ and a minimum of $36.84 \%$. Corresponding answers appropriate to a maximum of $60.53 \%$ and a minimum of $13.16 \%$, illustrated in red and green. lessappropriate answers are at a maximum of $23.68 \%$ and a minimum of $0.00 \%$. not appropriate answers are a maximum of $15.79 \%$ and a minimum of $0.00 \%$. 


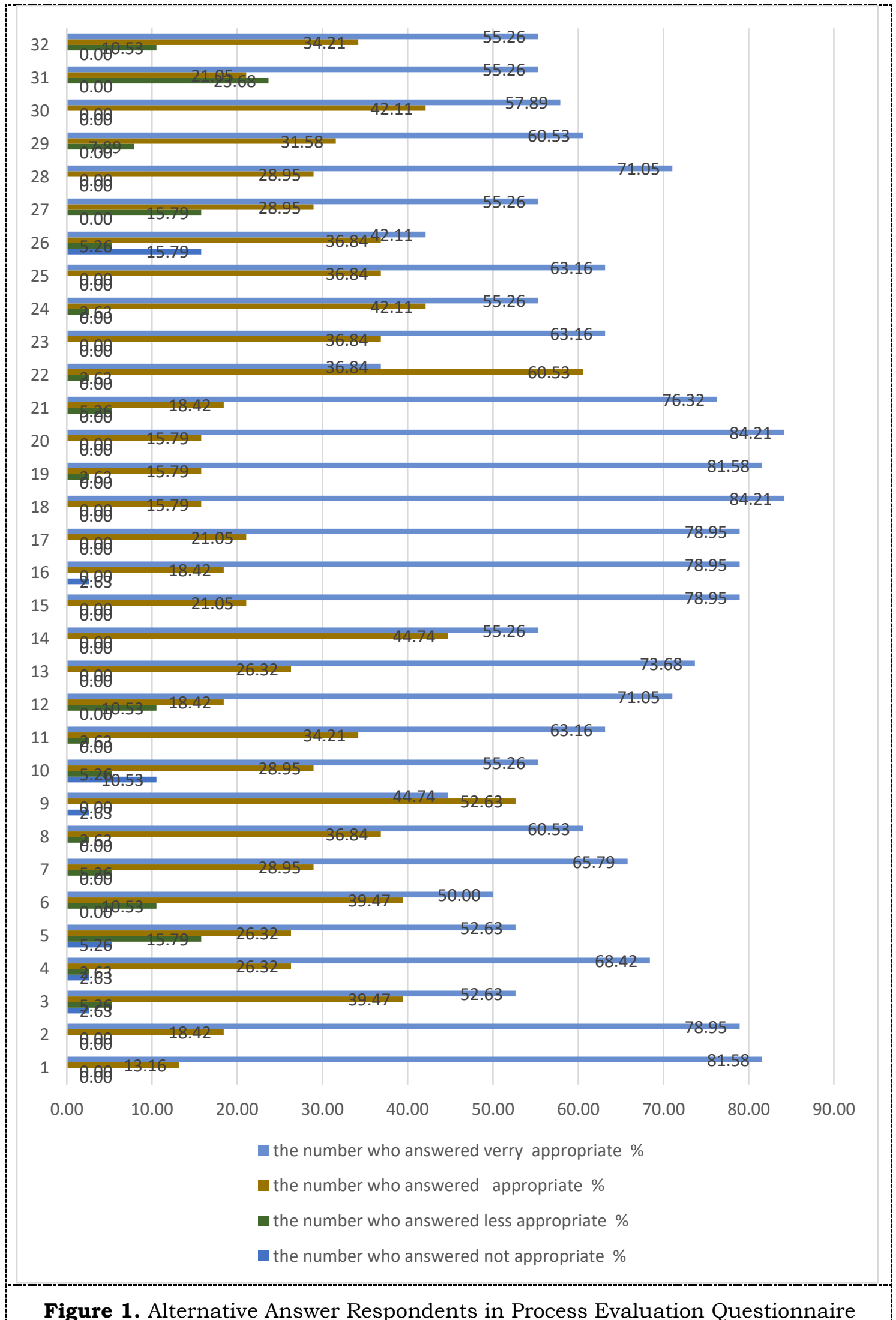

The instrument is presented in Table 8. 
Table 8. Respondents' answer to process evaluation

\begin{tabular}{|c|c|c|c|c|}
\hline $\begin{array}{c}\text { Item } \\
\text { Number }\end{array}$ & Instrumen question Item & The answer & amount & Percentage \\
\hline 5 & $\begin{array}{l}\text { The work plan (work schedule) } \\
\text { during the Field Work } \\
\text { Practices is prepared with the } \\
\text { DUDI supervisor written in a } \\
\text { workbook and notified to the } \\
\text { school supervisor }\end{array}$ & $\begin{array}{l}\text { less } \\
\text { appropriate }\end{array}$ & 6 & $15,79 \%$ \\
\hline 6 & $\begin{array}{l}\text { School advisers coordinate } \\
\text { with DUDI advisers on the } \\
\text { activities carried out by } \\
\text { participants in the Field Work } \\
\text { Practices }\end{array}$ & $\begin{array}{l}\text { Less } \\
\text { appropriate }\end{array}$ & 4 & $10,53 \%$ \\
\hline 10 & $\begin{array}{l}\text { School advisers monitor the } \\
\text { implementation of Field Work } \\
\text { Practices at least once }\end{array}$ & $\begin{array}{l}\text { not } \\
\text { appropriate }\end{array}$ & 4 & $10,53 \%$ \\
\hline 12 & $\begin{array}{l}\text { School advisers make } \\
\text { withdrawals of Field Work } \\
\text { Practice participants }\end{array}$ & $\begin{array}{l}\text { less } \\
\text { appropriate }\end{array}$ & 4 & $10,53 \%$ \\
\hline 26 & $\begin{array}{l}\text { School counselors always do } \\
\text { monitoring during the Field } \\
\text { Work Practices either come } \\
\text { directly or through telephone } \\
\text { communication }\end{array}$ & $\begin{array}{l}\text { not } \\
\text { appropriate }\end{array}$ & 6 & $15,79 \%$ \\
\hline 31 & $\begin{array}{l}\text { DUDI advisers regularly check } \\
\text { the diary and attendance list } \\
\text { of participants of the Field } \\
\text { Work Practice }\end{array}$ & $\begin{array}{l}\text { less } \\
\text { appropriate }\end{array}$ & 9 & $23,68 \%$ \\
\hline 32 & $\begin{array}{l}\text { DUDI advisers provide grades } \\
\text { for Field Work Practices } \\
\text { directly and are given to } \\
\text { school supervisors }\end{array}$ & $\begin{array}{l}\text { Less } \\
\text { appropriate }\end{array}$ & 4 & $10,53 \%$ \\
\hline
\end{tabular}

\section{Product Evaluation}

Data on product evaluation is collected through a questionnaire containing 10 questions with 4 alternative answers that are very appropriate, appropriate, less appropriate and not appropriate. Retrieval of data on product evaluation detailing the sub-variable achievement of the objectives to be achieved, the following results of the data obtained from the questionnaire.

In Figure 2, it can be seen that the tendency of respondents to answer the answers is very appropriate at a maximum of $81.58 \%$ and a minimum of $57.81 \%$. Corresponding answers appropriate to a maximum of $39.47 \%$ and a minimum of $18.42 \%$ which are depicted in red and green. less appropriate answers are a maximum of $10.53 \%$ and a minimum of $0.00 \%$. not appropriate answers for a maximum of $2.63 \%$ and a minimum of $0.00 \%$ instrument items that answer are less and do not match as follows. 


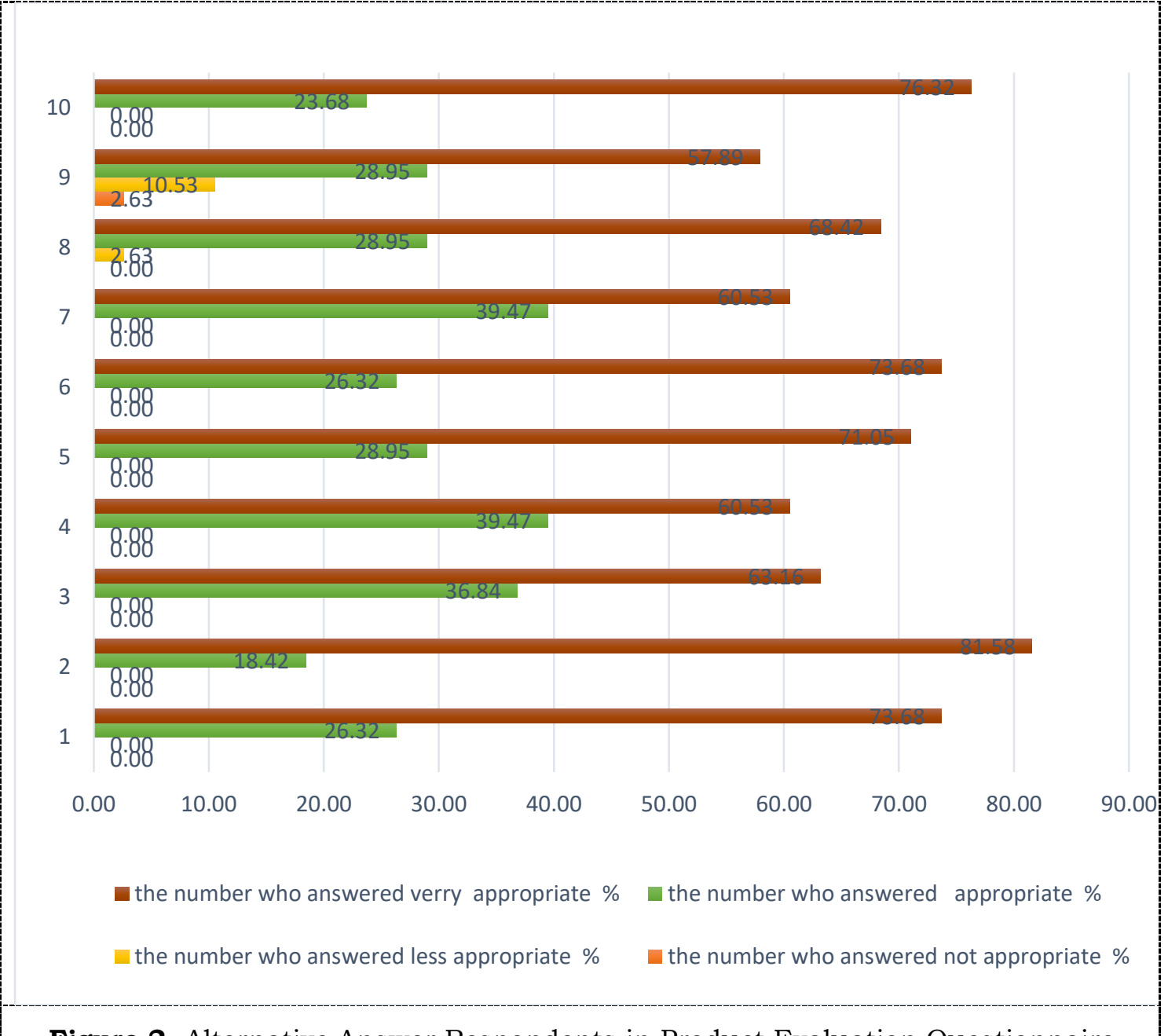

Figure 2. Alternative Answer Respondents in Product Evaluation Questionnaire

The instrument is presented in Table 9.

Table 9. Alternative Answer Respondents on the Product Evaluation

Questionnaire

\begin{tabular}{cllcc}
\hline $\begin{array}{c}\text { Item } \\
\text { Number }\end{array}$ & \multicolumn{1}{c}{ Instrumen question Item } & $\begin{array}{l}\text { The } \\
\text { answer }\end{array}$ & amount & Percentage \\
\hline 8 & $\begin{array}{l}\text { The Implementation of Field } \\
\text { Work Practices contributes to } \\
\text { the application of work culture } \\
\text { in the industry for Field Work } \\
\text { Practice participants }\end{array}$ & $\begin{array}{l}\text { not } \\
\text { appropriate }\end{array}$ & 1 & $2,63 \%$ \\
9 & $\begin{array}{l}\text { Field Work Practitioners get a } \\
\text { work experience certificate from } \\
\text { DUDI, used as work preparation } \\
\text { after graduation }\end{array}$ & $\begin{array}{l}\text { less } \\
\text { appropriate } \\
\text { and not } \\
\text { appropriate }\end{array}$ & 5 & $13,16 \%$ \\
& & & \\
\hline
\end{tabular}




\section{Discussion}

\section{Context Evaluation}

From the results of data processing from 8 questions that most of the respondents answered accordingly and were very appropriate, there were only a few respondents who answered less appropriate and not appropriate. Based on interviews with the coordinator/chairman Field Work Practices and school counselors as follows.

In question number 2, Participants in the Field Work Understanding understand about the Field Work Practice Briefing material provided by the school before conducting Field Work Practices. Respondents answered less appropriate and not suitable at $10.51 \%$. Based on the results of the interview, it can be analyzed that; The debriefing of Field Work Practices for participants before leaving the Field Work Practices was carried out classically by 107 students, this was an obstacle in the delivery of ineffective debriefing material. This is following the opinion of Wahyu Nurhajatmo (2008) stating that, before students are deployed to carry out industrial work practices, students need to be given a briefing. The briefing material is: (1) orientation of the business and industrial world, (2) tasks and obligations of students in the business and industrial industry, (3) instructions for filling in the apprenticeship books such as the journal of internship, making reports and so on, (4) reforming the attitude of students while in the industry, and (5) training in manners.

In question number 6, that DUDI as a Field Work Practice has a production/service process activity (routine work), so that street vendors do not get unemployed too often. Respondents answered less appropriate and inappropriate according to $15.79 \%$. Based on the results of the interview, it can be analyzed that; DUDI, where the Field Work Practice does not have a routine production/service process, so many students, are unemployed. DUDI accepts too many Field Work Practice participants, so many Field Work Practice participants are less effective in carrying out the practice.

\section{Input Evaluation}

From the results of data processing of 20 questions that the majority of respondents answered in accordance and very appropriate. There are only a few respondents who answered less accordingly and not accordingly, namely in the items questions 4,5, 6, 8 and 12. Based on interviews with the Working Practices Working Group and school supervisors, it can be analyzed as follows.

In question number 4 about DUDI where the Field Work Practice has more than 1. Employees the respondent answers inappropriate and less appropriate at $26.32 \%$. The results of the school supervisor interview that many DUDI Field Work Practice places that do not have employees. The work is done alone and is assisted by Field Work Practice participants. This has both positive and negative values. The positive value is that slim students can help practical work. The negative value is that students cannot experience varied communication and cooperation with employees.

In question number 5 about DUDI where the Field Work Practice has a clear division of tasks. Respondents answered inappropriate and less appropriate at $26.32 \%$. The results of the school supervisor interview that many DUDI Field Work Practice places that do not have a clear structure and division of tasks.

In question number 6 DUDI Field Work Practice has a safe and protected space/place of practice (K3) Respondents answered inappropriately according 
to $26.32 \%$. The results of the school supervisor interview that many DUDI Field Work Practices do not have complete equipment and K3 guarantees so that the practical work of injection vehicles cannot be done.

In question number 11 about the time for the implementation of the Field Work Practice for 6 months (either directly or interrupted 3 months-3 months). Respondents answered less according to $13.16 \%$. Based on information from the Field Work Practices working group that the implementation of Field Work Practices for 6 months is following government programs through the 2013 Curriculum.

In question number 12 about Participants in the Field Work Practices have sufficient preparation of knowledge and skills. Respondents answered less according to $26.32 \%$. Opinion Working Group Field Work Practice states that all participants have followed the debriefing of Field Work Practices. It is hoped that all students will have sufficient knowledge and skills preparation. However, due to constraints in school learning facilities that are lacking, so the school year 2019/2020 class XI students carry out Field Work Practices earlier (July 2019). The students' knowledge and skills are not enough as capital to carry out fieldwork practices

In question number 20 about the Working Practices Working Group recapitulates the DUDI Field Work Practices and determines the Field Work Practices Guidance for each participant of Field Work Practices. Respondents answered that it was not appropriate at $7.89 \%$. The Field Work Practices Working Group has conducted DUDI data collection and the determination of Field Work Practices advisers, but socialization to students is still lacking.

\section{Process Evaluation}

From the results of data processing of 32 questions that the majority of respondents answered accordingly and are very appropriate, there are only a few respondents who answered less appropriate and not suitable there are only a few respondents who answered less appropriate and not appropriate, namely on the questions 5. 6, 10, 12, 26, 31 and 32. Based on interviews with the Coordinator/chairman of Field Work Practices and school counselors can be analyzed as follows.

In question number 5, the work plan (work schedule) during the Field Work Practices is prepared with the DUDI supervisor written in a workbook and notified to the school supervisor. Respondents answered that it was less appropriate at $15.79 \%$. Based on information from the Field Work Practices supervisor, that the school supervisor when submitting the first time the Field Work Practices students cannot meet with Industry Counselors, because of the busywork at the workshop. As a result, coordination is still lacking. This opinion is reinforced by Mardi Rasyid (2008: 215) which states that the industry which is a school partner has not been able to participate in planning student learning activities in shaping student professionalism.

In question number 6 , about the school supervisor coordinating with the DUDI supervisor about the activities undertaken by the participants in the Field Work Practices the respondents' answers do not correspond to 10.53. Based on information from the Field Work Practices supervisor, that the school supervisor when submitting the first time the Field Work Practices students cannot meet with Industry Counselors, because of the busywork at the workshop. As a result, coordination is still lacking

IJEI, Vol. 1, No. 1, April 2020, 41-60 
In question number 10, the school supervisor monitors the implementation of the Field Work Practice at least once. Respondents answered incorrectly at 10.53. Based on information from the school supervisor, that the school supervisor conducts guidance and coordination with DUDI at least 3 times, that is, when submitting, monitoring and withdrawing PKL students

In question number 12 about the school supervisor pulling out the fieldwork practice participants. Respondents answered less appropriate at $10.53 \%$. Based on information from the school supervisor, the school supervisor conducts guidance and coordination with DUDI a minimum of 3 times, namely, when submitting, monitoring and withdrawing students from the Field Work Practice.

In question number 26, about the school supervisor always doing monitoring during the Field Work Practice either directly or via telephone communication. Respondents answered incorrectly at $15.79 \%$. Based on information from the school supervisor, when monitoring to DUDI, sometimes they do not meet with students, because the Field Work Practice schedule students use the morning or afternoon shift, so students do not meet the school supervisor.

In question number 31, about the DUDI Advisor, regularly check the daily logbook and attendance list of participants in the Field Work Practice. Respondents answered less appropriate at 23.68\%. The DUDI adviser is too busy with the work of the workshop so that he does not have time to check the activity records every day.

In question number 32, about the DUDI Supervisor where the Field Work Practice provides the value of the Direct Job Training and is given to the school supervisor the respondent's answer is less than 10.53\%. Based on information from the Field Work Practices Working Group, that most DUDI provides direct Field Work Practice scores, but some DUDI workshops end up students who judge. This question is following the Field Work Practice Evaluation Program from Dikmenjur (2005: 9) "Evaluation of the implementation of industrial work practices is carried out in the industry, as evidence that the evaluation of the internship competency of students has obtained certification from industry". Meanwhile, according to Nokler in Tatang (2000: 35) states "the instructor gives value to the results of the practice work and participates in administering the exam."

\section{Product Evaluation}

From the results of data processing of 10 questions that the majority of respondents answered according to and very appropriate, there were only a few respondents who answered less appropriate and inappropriate, namely numbers 8 and 9. Based on interviews with the Field Work Practices Working Group and school supervisors as follows.

In question number 8, the Implementation of Field Work Practices contributes to the application of work culture in the industry for the participants of the Field Work Practices Respondents answered incorrectly by $2.63 \%$. Based on interviews and data from the Field Work Practices Working Group team, it can be concluded that the implementation of Field Work Practices in informal workshops does not pay much attention to the values of industrial work culture. So some students give the wrong answer

In question number 9, that the Field Work Practice Participants get a work experience certificate from DUDI, used as work preparation after graduation. 
Respondents answered that it was not appropriate and not suitable at $13.16 \%$. Based on interviews and data from the Field Work Practices working group team, it can be concluded that the Field Work Practices certificate is issued by the school, the DUDI Advisor only validates it. DUDI does not issue a certificate of Field Work Practices, this causes the certificate value to be less when students will register with the company.

The results of the discrepancy analysis of the respondents' answers to the questions in the context evaluation, input evaluation, process evaluation and product evaluation, following the opinion of Sonhadji (1997), the implementation of Fieldwork Practices faces obstacles, as follows: (1) Delegation of tasks and responsibilities among the organizational tools of the Fieldwork Practices Working Group has not been evenly distributed, and there is a dominant tendency for the Chairperson of the Working Group, (2) Tutor teachers are not functioning optimally in the industry, and some of them are not relevant to their fields, (3) Difficulties in collaborating with partner institutions that are classified as medium and large, (4) The low management of the management of student training by industry, especially in small industries, (5) Many industry instructors do not meet the requirements and have not played an effective role, (6) There are still many students who are looking for industrial training places themselves, (7) Lack of time provided by the School Working Group to coordinate, (8) The duration of licensing and training requests, (9) Lack of discipline and low awareness of students for work safety; (10) The imbalance between the number of SMKs and the number of businesses/industries.

\section{CONCLUSION}

The implementation of the Job Training Program generally aims to; 1). Provide direct work experience (real) to instill (internalize) a positive work climate that is oriented to care about the quality of processes and work results.2). Instilling a high work ethic for students to enter the workforce facing the demands of the global labor market. 3). Meet things that have not been met in schools to achieve the integrity of graduate competency standards. 4). Actualize the implementation of the Dual System Education Model (PSG) between Vocational Schools and Institutional Pairs (DUDI), integrating systematically and systemically the educational programs in Vocational Schools and the training programs in the world of work (DUDI).

To realize the objectives of the Field Work Practices, all components involved in organizing the Field Work Practices program are interrelated and work together with each other so that the implementation of Field Work Practices runs following the Field Work Practices guidelines that have been formulated by the Vocational Schools.

General description of the Implementation of Field Work Practice Competence in Automotive Light Vehicle Engineering expertise in class XI students of SMK Negeri Nusauwngu 2018/2019 Academic Year, taken through; questionnaire, interview, and documentation to students, the Field Work Practices Working Group and the Chair of Expertise Competencies. While the data regarding the suitability of Industry Practices based on the Field Work Practices handbook is measured through a Questionnaire and then elaborated and reduced and summarized ie starting from; Context Evaluation, Input Evaluation, Process Evaluation, Product Evaluation.

From the results of the questionnaire reduction, interviews and documentation can be concluded that the implementation of the Field Work

IJEI, Vol. 1, No. 1, April 2020, 41-60 
Practices of Automotive Light Vehicle Engineering Competence in SMK Negeri Nusawungu is as follows.

1. Evaluate the context

The suitability of the Field Work Practices program from Schools and DUDI is largely following the objectives of the Field Work Practices.

2. Evaluate inputs

a. Requirements required by students before starting the Job Training are mostly following the Job Training program.

b. The preparation that students must make before carrying out the Job Training is largely appropriate.

3. Process Evaluation

a. Information regarding the implementation of Work Practices L is following the PKL guidelines determined by the school.

b. The process of implementing students when implementing street vendors in the industrial world is following the street vendors guidelines.

c. The process of completing reports and practice exams after students carry out fieldwork practice in the industrial world following fieldwork practices guidelines.

d. The role of the PKL Coordinator / Chairperson is largely following the duties of the DUDI supervisor.

e. The role of the internal tutor is following the functions and duties.

f. The role of mentors from the industrial world (external).

4. Product Evaluation

Achievement of the implementation of the Job Training with the aim of the Job Training is appropriate.

\section{REFERENCES}

Arikunto, S., \& Cepi S. A. J. (2004). Evaluasi Program Pendidikan Pedoman Teotitis Praktis Bagi Praktisi Pendidikan. Jakarta: Bumi Aksara.

Badeni. (2002). Relevansi SMK Berpendidikan Sistem Ganda (PSG) dengan Kebutuhan Pasar Kerja di Indonesia. Jurnal Pendidikan dan Kebudayaan, 8(38), 710-725.

Depdiknas. (2005). Panduan Praktik Kerja Industri. Jakarta: Depdiknas.

Dikmenjur. (2005). Pendidikan Sistem Ganda. Jakarta: Depdiknas.

Dikemendikti. (2003). Undang - Undang. Praktek Kerja Industry (Prakerin). Retrieved from: http://kal.dikmendikti.go.id/download/SK_PKAL.doc.

Dikmenjur. (2008). Prakerin Sebagai Bagian Dari Pendidikan Sistem Ganda. Retrieved from: http://www.geocities.com/dit_ dikmenjur/prosedur_prakerin.htm.

Hamalik, O. (2004). Proses Belajar Mengajar. Jakarta: PT.Bumi Aksara.

Hamalik, O. (2007). Manajemen Pelatihan Ketenagakerjaan Pendekatan Terpadu Pengembangan Sumber Daya. Jakarta: Bumi Aksara.

Rasyid, M. (2008). Dukungan Industri terhadap Keberhasilan Pendidikan Sistem Ganda di Sumatera Barat. Forum Pendidikan, 23(1), 53-67.

Oktavia, M. (2014). Kontribusi Pengalaman Prakerin dan Kompetensi Kejuruan terhadap Kesiapan Memasuki Dunia Kerja Industri Siswa Program Teknik 
Komputer dan Jaringan Kelas XII di SMK N 2 Padang Panjang. Jurnal Vokasional Teknik Elektronika dan Informatika, 2(1).

Pardjono. (2011). Peran Industri dalam Pengembangan SMK. Retrieved from: http:// staff.uny.ac.id/system/files/pengabdian/prof-drs-pardjono-mscphd/peran-dudi-utk-smk.docx.

Sugiyono. (2012). Metode Penelitian Pendidikan (Pendekatan Kuantitatif, Kualitatif dan R\&D). Bandung: ALFABETA.

Sugiyono. (2012). Metode Penelitian Kuantitatif, Kualitatif dan R\&D. Bandung: ALFABETA.

Sukardi. (2011). Evaluasi Pendidikan: Prinsip dan Operasionalnya. Jakarta: Bumi Aksara.

Nurhajatmo, W. (2008). Evaluasi Implementasi Kebijakan Pendidikan Sistem Ganda di Sekolah Kujuruan, Jurusan Administrasi Negara. Thesis. Surakarta: FISIP Universitas Sebelas Maret.

Djojonegoro, W. (1998). Keterampilan Menjelang 2020. Jakarta: Departemen Pendidikan dan Kebudayaan.

Djojonegoro, W. (1998). Peningkatan Kualitas SDM Melalui Pendidikan dan Kebudayaan. Jakarta: Jayakarta Agung Offset.

Djoyonegoro, W. (1998). Pengembangan Sumber Daya Manusia Melalui Sekolah Menengah Kejuruan (SMK). Jakarta: Agus Offset.

Wena, M. (1997), Pemanfaaan Industry Sebagai Sumber Belajar Dalam Pendidikan Sistem Ganda. Jurnal Pendidikan Kebudayaan, 3(10).

Wirawan. (2011). Evaluasi: Teori, Model, Standar, Aplikasi, dan Profesi. Jakarta: PT Rajagrafindo Persada. 